\title{
HIV/AIDS among the elderly: stigmas in healthcare work and training
}

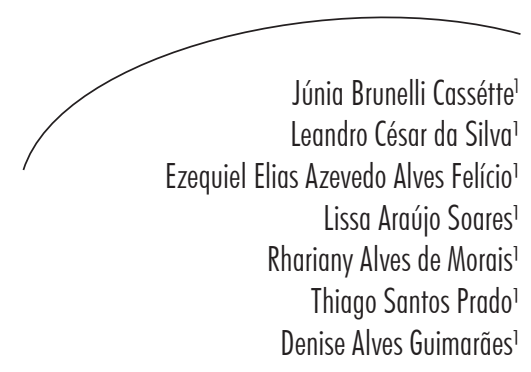

Abstract

The number of HIV/AIDs diagnoses among the elderly is currently increasing both in Brazil and on a global level. The present article describes the results of a qualitative study which aimed to assess the role of health professionals on elderly patients diagnosed with HIV/AIDS receiving treatment via the public health service. Nine professionals who made up a specialized HIV/AIDS service in a medium-sized city in the state of Minas Gerais were interviewed. Their statements were subjected to content analysis, and the results suggested that according to the perceptions of the health professionals, the main impacts of the diagnosis of HIV/AIDS are linked to isolation, loneliness, prejudice, fear of revealing the diagnosis and the decrease or interruption of sexual practices. The professionals reported being overburdened both psychologically and in terms of workload, having difficulty addressing aspects of sexuality and sexual practices with the elderly, and admitted to possessing certain stereotypes and prejudices related to HIV/AIDS and the sexuality of the elderly. Through results analysis, it was concluded that the stigma and prejudice related to HIV and the sexuality of the elderly are intimately present in the work processes of the professionals interviewed, impacting on the treatment of such individuals and interfering with their health and illness processes. The discussion of these aspects should be included in health training strategies.

Keywords: Aging. HIV. Social Stigma. Professional Training.

Universidade Federal de São João Del Rei, Campus Centro-Oeste, Curso de Medicina. Divinópolis, MG, Brasil.

Correspondence

Denise Alves Guimarães

E-mail: alvesguimaraesdenise@gmail.com 


\section{INTRODUCTION}

We live at a time when Human Immunodeficiency Virus (HIV) infections are increasing in Brazil ${ }^{1}$ and around the world. According to an epidemiological study conducted by ATHENA, Holland will experience an increase in mean age from 43.9 to 56.6 years. It is estimated that the number of patients aged 50 years or more who are infected with HIV will increase from $28 \%$ in 2010 to $73 \%$ in $2030 .^{2}$ The number of AIDS cases among the elderly population in Brazil has skyrocketed in recent years. Between 1980 and 2001, the number of people aged 60 years or more who were diagnosed with AIDS was 5,410. Between 2002 and 2014, this figure was 17,861. These figures suggest that in a period of 21 years, there was a mean variation of 257.61 cases per year, whereas in the subsequent 12 years, this variation increased to 1488.41 cases per year (a variation of $577.77 \%)^{3}$

Brazil is a notable case in relation to population aging. Between 1950 and 2025, the number of elderly individuals is expected to have increased fifteen fold, when compared with data from the 1950s. ${ }^{4}$ These alterations to the composition of the population represent a challenge for society in general, particularly for health professionals who deal with elderly individuals on a daily basis. These professionals seek to associate longevity with quality of life, while considering changes to economic, sanitary and social conditions, including sexuality as a right of the elderly. ${ }^{5,6}$

Throughout the history of humanity, sexuality and prejudice have been interconnected. The prejudice related to the sexuality of the elderly dates back to the repression that existed for centuries in society, at a time when sexual activity was only associated with reproduction. ${ }^{7-9}$ Although the sexual performance of the elderly has benefited from scientific and technological advances, increased life expectancy and an improved quality of life, there is a growing concern about sexually transmitted infections (STIs) in this section of the population. ${ }^{10,11}$ At the same time, stereotypes and prejudice linked to the myth of the asexuality of the elderly refuse to disappear. ${ }^{5,7,8}$

Among the stereotypes and transformations that accompany the aging process, there is now the possibility of a seropositive diagnosis for HIV. This virus must also be analyzed in terms of its potential for stigmatization ${ }^{12}$, its effects on the identity of individuals, groups and social relationships, and the relevant repercussions that are specific to health-disease processes. The stigma is a social construct, born of the relationship between individuals and the social stereotypes that define (in a symbolic or concrete fashion) the boundaries of normality. ${ }^{13}$ Going beyond the limits defined for what is considered socially normal can lead to discrimination, accompanied by accusations, isolation, rejection and the adoption of punitive and corrective measures, both on behalf of the socalled "normal" subjects and those who are being stigmatized. This stigma attributes an individual or group with a certain character that guides their entire network of personal relationships and when internalized, dominates their references to the self, their feelings and even their attitudes, generating guilt, shame, anger, confusion and a disorganized identity. ${ }^{14,15}$

Concerning HIV infection, a seropositive individual can be included in the stereotype of "AIDS-ridden" and may be classified in a wronglynamed risk group ${ }^{14,15}$, with all the moral weight of this classification. In addition, when an elderly individual is diagnosed with HIV/AIDS, it is often very surprising, unexpected and difficult to accept, since it is contrary to certain stereotypes that are specifically linked to the elderly, particularly the notion of asexuality in this stage of life.

In terms of the specificities of health professionals who work with patients living with HIV/AIDS, literature suggests that these patients deal with the following issues: fear; uncertainty related to dealing with news that causes suffering and is irreversible; stigmas and prejudice related to HIV/AIDS that link the disease to drug addiction and socially questionable sexual habits; issues 
related to suffering and social exclusion; and concerns about the finiteness of life. ${ }^{16,17}$

This situation challenges health professionals to undertake critical and reflective thinking about their patients on a daily basis. Thus, the present study could help clarify the complexity of providing health care services and the different aspects that affect the daily lives of these health workers, including the relationship between health practices and stereotypes about the disease and the sexuality of elderly individuals who live with HIV/ AIDS. It is extremely important that these aspects are considered, both in terms of planning public policies that promote the health of the elderly, and in relation to permanent training and education strategies for the health sector. ${ }^{18,19}$

Therefore, the aim of the present study was to analyze (in general terms) the activity of health professionals who work with HIV-positive elderly individuals in the public health sector. More specifically, we sought to identify the perceptions of these professionals in relation to the impacts of this diagnosis, the specificities of their work, as well as the difficulties and challenges they face.

\section{METHOD}

Given the complexity, specificities and multidisciplinary nature of the health sector, this was a qualitative, exploratory study. ${ }^{20}$ All health professionals who were directly involved in dealing with elderly individuals at a public health unit that specialized in STIs in a medium-sized city in the Brazilian state of Minas Gerais were considered for this research. The municipality in question was the reference point for the 55 municipalities in the region. According to DATASUS records, the service monitored 726 patients with HIV/AIDS in 2012, of whom 40 patients were over 60 years of age $\left(8.26 \%\right.$ of the patients monitored) ${ }^{21}$

The present study focused on health professionals who make up the Serviço de Assistência Especializada (Specialized Care Service) (SEC) in the municipality, all of whom accepted the invitation to participate. Semi-structured interviews were conducted with all nine individuals (three men and six women), who worked in areas such as medicine, nursing, pharmacy, psychology and social care. Seven of these professionals were in a high-level position and the remaining two were in mid-level positions. Between February and October of 2012, individual semi-structured interviews were conducted and recorded. These were later transcribed and submitted to content analysis, following the thematic or categorical analysis protocols defined by Bardin. ${ }^{22}$ During the analysis, the content was grouped based on prevalence in the comments made by the interviewees and the thematic proximity of the core feelings that emerged. The content of the comments analyzed was organized into three categories: 1) the perception of the health professionals about the impacts of a diagnosis of HIV/aids on the elderly individual; 2) care for seroconverted elderly individuals; 3) daily difficulties faced by health professionals in their work. The work of Goffman was adopted as the main theoretical analysis reference for the process of stigmatization and its impacts on the identity and socialization of the individuals in question. Other discussions that considered this reference when analyzing the impacts of the HIV/AIDS epidemic were also used. ${ }^{13-15,19}$

The present study was approved by the Research Ethics Committee of the Universidade Federal de (São João Del Rei Federal University) (Campus Centro-Oeste) under protocol number CEP-UFSJCCO 006/2011. All ethical issues were respected and the health professionals interviewed confirmed their willingness to participate by signing a free and informed consent form.

\section{RESULT AND DISCUSSION}

Before presenting and discussing each of the analysis categories, it is important to stress that the themes of stigmas and prejudice run through all of these. These themes were present in the perspective of socially-constructed stereotypes 
about disease and the sexuality of the elderly. This often reflected prejudice on behalf of the elderly individuals about themselves and their new health condition, as well as the stigma and prejudice applied by health professionals in relation to HIV/AIDS and the sexuality of the elderly. Thus, it is possible to state that the link between aging and HIV/AIDS is a category that has shown its stigmatizing potential in two associated areas: the attributes that produce a discrediting effect in the subject and are linked to the illness; ${ }^{19,23,24}$ and the incongruities that the diagnosis of HIV/ AIDS presents in relation to the stereotypes linked to elderly individuals, particularly the notion that they are in a sexless phase of life. ${ }^{7,8}$

The results and discussions presented below follow the above mentioned analysis categories and address the specificities of the issue of stigmas and prejudice linked to aging with a diagnosis of HIV/aids.

The perception of health professionals about the impacts of a diagnosis of HIV/AIDS on the elderly individual

This category presents and discusses the perceptions of health professionals about the impacts of a diagnosis of HIV/AIDS on the elderly individuals, and is split into the following subcategories: 1) changes in affective relationships with family members, friends and partners; 2) changes to their social life and sexual practices; 3 ) prejudice and its implications in terms of treatment.

In general, all of the health professionals interviewed claimed to notice some form of impact in relation to a diagnosis of HIV/AIDS on elderly individuals who kept in touch with the health service unit. The most commonly-mentioned impacts were: sadness; denial; loneliness; social isolation; distancing themselves from people, groups and daily activities; surprise, shame and embarrassment related to acquiring the virus at this stage of life; disbelief (about the diagnosis); and concern about possible prejudice they might face if people discovered the fact that they had been infected.
Health professionals from the fields of medicine, nursing, social services and psychology who treat elderly patients with HIV/AIDS requested that more attention be paid to the impact of the diagnosis on the patient and highlighted the need for multi-professional support, as highlighted in the following comments:

"It starts with sadness. Lots of them cry. Many others become introspective. Sometimes we have to (...) interrupt the appointment and ask for a psychologist to help, before starting the appointment again. Its sadness, and surprise. They are surprised as they never expected to get a positive result". Med. 2

"They sit down, like this, and they feel worthless, like a piece of dirt. They feel like the world has ended and say that they will not live anymore". Serv. Social

Therefore, they distance themselves from friends, neighbors and workmates in order to maintain the confidentiality of their health condition They are extremely frightened of being exposed to discrimination and prejudice.

Often, family members of patients will not accept the fact that the elderly individual is sexually active, which is confirmed by the diagnosis with HIV/AIDS. Many family members are surprised by the diagnosis or doubt its accuracy as they find it impossible to imagine the sexual transmission of the virus in this stage of life.

With the exception of one of the health professionals, who did not develop any strong bonds with patients and maintained a quite restricted and purely technical relationship with them, the remainder noticed the following negative effects in the social lives of seropositive elderly individuals: isolation; distancing themselves from work, religion and leisure activities. The professionals found that all of the patients were extremely afraid of suffering prejudice and discrimination. They also noted that many elderly individuals were impacted financially by the transport costs involved in travelling to the health center and attempts to improve their diet. These impacts can be exemplified by the following comments: 
"Many of them do not tell their social groups. Some of them even say that it has distanced them from their social groups. This is worrying for us. Sometimes they say "I used to go to (...) church (...), the dancehall at the weekend, but I don't go anymore." "Why don't you go anymore?", "I'm worried that somebody might say something, and a friend of mine might find out what I have" Med. 2

It is also worth highlighting the perception of a psychologist who felt that elderly individuals who were diagnosed with HIV/AIDS believe that they are judged by other individuals by sight, even when these others do not know about the diagnosis:

"It is normal for them to distance themselves a bit from their sports and social activities, if they have them. Some of them seem to think that people will be able to tell just by looking at them that they have caught something. Obviously, this must be linked to how they see themselves now that they have HIV. We say that society shows prejudice against these patients, but the patients show prejudice against themselves too. It's almost like magic. They think that others will know "I have a sex life, or worse, that I am promiscuous". Psy. 1

The health professional who claimed not to have developed any bond with the patients did not notice any differences in their social lives and believed that they are in a "stagnant" phase of life, given that they were retired from the workforce and they did little physical activity. This perspective demonstrated that this particular health professional had a generalized and stereotypical view of the elderly and old age, with strong links to inactivity and decadence. ${ }^{5,8}$

Of the nine professionals interviewed, eight spoke of the negative effects on the sexuality and sexual practices of the elderly individuals after they had been diagnosed with HIV/AIDS. Usually, these effects involved the interruption or cessation of sexual activity. They noted that the greatest difficulties were linked to the use of preservatives, the fear of infecting somebody and the fear that new partners would be afraid of their condition as a seropositive individual. Some of the professionals believed that the diagnosis led to the decrease of sexual activity among men and the cessation of sexual activity among women.

The changes noticed by the health professionals in the social life, sex life and sexual practices of seroconverted elderly individuals are addressed in the comments below:

"I have had the opportunity, during my guidance sessions, to talk to these individuals and one male patient made it clear that he simply preferred to stay at home. He is alone... I don't know if he is separated, he doesn't have a partner. So he says that his life is very sad, as it will be impossible for him to find somebody at this stage in life, with this diagnosis. So he prefers to stay home watching television and..... he put it like this: "how am I going to stay at home without drinking and smoking? That's all I have left". So it's difficult for us to push them on this matter. They feel so alone". Pharm. 1

One of the health professionals interviewed did not notice any alterations in the sexual practices of the seroconverted elderly individuals, as he or she did not ask the patients this type of question, despite the fact that it was his or her responsibility to instruct them in the use of condoms. In addition, two other health professionals reported that they did not directly address this subject with elderly patients, as they found it difficult to bring up or felt that it was not relevant to their professional activity. They also said that when this topic arose, it was brought up by the elderly patient.

Despite the different levels of involvement on behalf of the health professionals with the elderly individuals they treated, all of the interviewees noticed that the patients had experienced discrimination due to the fact that they were seroconverted and did their utmost to ensure that nobody would know about their diagnosis (for fear of suffering prejudice). They also stressed that the prejudice related to HIV/AIDS began with the patient themselves, but was also common from other members of their social groups and even their own family, as can be seen in the following comments:

"In the beginning, when the patient arrives, it is very important to welcome the family as well, because sometimes 
the prejudice begins at home, due to ignorance, and the discriminating nature of people. It is not a question of age, sometimes the children know a lot more about it. They are younger and can be even more prejudiced. So we have to advise them. They think that they need to separate the things that belong to the patient in the home. This is a very common issue. They separate bedclothes, cutlery, soap... they completely change the person's routine in the home. We have to make continuous clarifications, such as "the virus cannot be passed on in that way", so that they suffer less. If it starts in the family, it is even worse. This prejudice is still very common...they suffer a lot because of this". Psy. 2

It is important to highlight the observations made by professionals from the areas of nursing, medicine and psychology in relation to the association between the diagnosis, prejudice linked to the illness, treatment issues and the intensification of suffering. Since treatment is designed to combat the illness, it also confirms its presence, and may generate reminders about the prejudices suffered, while also possibly leading to situations that prevent the individual from keeping their diagnosis a secret, such as the storage and handling of medication. These issues are quite often interconnected and were discussed by the professionals in terms of the repercussions in the adherence to treatment:

"In my experience, prejudice is one of the most significant difficulties. The treatment in itself has brought about results and has been shown to be effective when patients accept that they have HIV and accept the treatment, regardless of whether they need to take drugs at that stage or not. However, sometimes, as a result of prejudice, from themselves and their social circles, the patients create situations of avoidance, and the treatment plan brings this to the fore. So, sometimes they prefer not to come (to the clinic). They think they can magically ignore the prejudice, and not be affected by it. They think they will not be bothered by it, so it's better not to go ahead with the treatment, or something like that. Therefore, prejudice is a great hindrance to the treatment in itself. People hide and stop coming for treatment because the treatment forces them to face their situation head on. This is related to the prejudice they have against themselves as well. Of course, there is this issue of accepting the situation, admitting it, and upon admitting it saying "I will be responsible for my treatment". I think prejudice can interfere somewhat in this process and prevent it from flowing smoothly. Psy. 1
Studies have reported that seroconverted individuals experience depression, guilt, shame, anger, fear, rejection, isolation and a drastic reduction (or even a cessation) of sexual intercourse. ${ }^{25}$ These aspects have been addressed in both scientific literature and in the reflections of the health professionals interviewed in the present study, and help to clarify the complexity of health promotion, the specificities of health care services and the current challenges facing professionals who work with HIV patients.

These aspects are closely associated with the processes of stigmatization, social stereotypes, prejudice and the repercussions for the health of the individual. The process of stigmatization is reflected in the manner in which the subject perceives themselves, as well as the interpersonal relationships they establish. For people who live in a stigmatizing condition, contact with people who live within the boundaries of normality can generate many difficulties, so they tend to make an effort to avoid contact and keep their stigmatizing condition a secret. ${ }^{14}$ Thus, it is possible to infer that an understanding of this process of stigmatization and its repercussions is essential for the adequate management of HIV-positive elderly individuals and their families.

\section{Caring for seroconverted elderly patients}

This category addresses the perceptions of the health professionals in relation to caring for elderly individuals with HIV/AIDS, including their first experiences with these patients, the specificities involved in caring for these patients and the challenges faced while providing this care.

Five health professionals stated that when they first started to receive patients with STIs/ AIDS, they expected to have elderly patients, as they believed that the transmission of the virus can occur in several situations and that sexual practices are commonplace among the elderly. The remaining four interviewees (who had either a high school or higher level education) stated that they did not expect to receive elderly patients as they did not think that people of that age were so 
sexually active, or because they associated HIV/ AIDS with previously established "risk groups", which do not include the elderly. However, when they discussed their first experiences with HIVpositive elderly patients, six health professionals (who had either a high school or higher level education), including some of those who had said that they expected to work with elderly patients, were surprised and found it difficult to believe the HIV/AIDS diagnosis for the elderly patient, mainly due to prejudice, cultural ideas and notions about risk groups. The following comments demonstrate these different reactions:

"Yes, I expected it [receiving HIV-positive elderly patients] because I don't believe that sexuality ends when you get old. There is no start date and end date for sexuality. It has improved really for the elderly hasn't it? Now, they have Viagra, they have information, they have a better quality of life. All of this favors a prolonged sex life. And if we conduct a review of out predecessors, they had sex lives at eighty, seventy years of age". Nur. 1

"But when I started to see people of 70 or 80 years of age, I was a bit shocked. I was not aware of the extent of their sexual activity. I didn't realize that these meetings for the elderly led to so many contacts. They are sexually active and many are promiscuous. Promiscuity also exists among the elderly. So these group meetings, these dances for the elderly, often lead to a significant frequency of sexual relations. I hadn't really imagined the level of sexual activity among people of this age". Med. 1

"I really changed how I looked at people after coming here. It is a form of prejudice, but we had an "image" of who would have these diseases. So I was very surprised to see people like this.... I would never have thought that this type of person would be infected. Nowadays, I tell my children all the time that appearances are deceiving. They don't mean anything anymore. You might have thought that somebody with this virus would already show signs of sickness, they would be weak, or they would be homosexual, or a transsexual, wouldn't you? You had that old-fashioned concept that only those who had same-sex relationships ran the risk of catching the virus. Well, you are wrong. I have seen old married women who have become widows, young married women whose husbands are truck drivers. I have seen beautiful young girls who have the virus, they don't have AIDS, they just have the virus. And if you see them in the street, you would never in a million years imagine that they have a contagious virus that could contaminate thousands of people”. Nur. 2
Two of the interviewees claimed not to remember their first experiences and refused to participate in this discussion. It is important to stress that the comments presented demonstrate how much these stereotypes and prejudices related to the sexuality of the elderly can be rooted in the perceptions of health professionals. They may even comprehensively associate it with promiscuous behavior, which was not confirmed in the contamination history of the elderly patients who attended the health clinic in question. Perhaps their refusal to discuss this subject was due to their embarrassment related to their own prejudices.

Based on their experiences, the professionals analyzed different specificities involved in caring for the elderly: 1) health professionals must pay close attention to the elderly patient, to identify if they see the patient as a sort of grandfather figure, and to heed their greater vulnerability; 2) health professionals need to pay closer attention to difficulties related to aging, such as poor sight, impaired hearing or a poor understanding of complicated prescriptions; 3 ) health professionals must use simple language, due to the lower level of education or illiteracy that is common in the elderly population; 4) health professionals must be able to talk with elderly individuals about the prevention of sexually transmitted diseases, regardless of the difficulty of the health professional or the patient in broaching the subject; 5) the technical ability of the professional is paramount, since managing HIV/AIDS in elderly patients is more complex due to the comorbidities and medical complications that are commonplace in this age group.

Converging with the above mentioned specificities, the challenges indicated by the health professionals when discussing care for HIV-positive elderly individuals were: 1) from the point of view of the organization of health services, the interviewees mentioned that their extensive workload led to a lack of time to provide more appropriate care for elderly patients and their specific requirements; 2) from the point of view of health education and preventive actions, they stressed the need for greater adherence to the use of condoms and medicine among the elderly population; 3) they felt that strategies must be developed to adequately deal with the difficulties 
linked to addressing sexual habits with elderly patients, as a result of the lack of debate on the subject, or the level of misinformation about the subject, or their own difficulties in how to discuss these issues with elderly patients; 4) more patience is required with elderly patients in order to clearly explain their diagnosis, treatment and prevention methods, considering both their limited education levels and the possibility that the HIV may already have accelerated neuropsychic disorders; 5) from the point of view of the training of the health professionals, it is necessary to provide constant updates concerning the technical management of HIV/AIDS and its comorbidities among the elderly.

The comments of all of the health professionals, to a greater or lesser degree, demonstrated the perception of the daily presence of stereotypes, stigmas and prejudice related to HIV/AIDS in the lives of the elderly and their impact on healthdisease processes. However, the perception of the impact of these stereotypes, stigmas and prejudice on the reactions of the professionals themselves when faced with a diagnosis of HIV/AIDS, as well as the impact of these issues on their professional practice, vary from person to person.

This variation does not seem to be linked to the level of education or indeed the area of expertise, but rather the bond that has been established with the patient, as well as the interest and understanding of the professional in a more extensive health approach and concrete opportunities to analyze and critically assess their professional practice in relation to the prejudices found in society, thereby creating subjectivity. Concerning professional training, permanent educational activities and health promotion strategies, it is important to stress the significance of including the issue of stereotypes, stigmas and prejudice related to health-disease processes. Furthermore, it is essential to provide health training that is more focused on critical thought and reflection on daily health practices. ${ }^{26}$

Studies have reported that campaigns planned by public policies and health professionals themselves include (to a certain extent) the notion that only drug addicts and individuals who engage in certain sexual practices are at risk of contracting STIs/ AIDS, with the clear suggestion that the elderly are not at risk. This perspective affects the request of HIV tests, thereby compounding the difficulty of professionals when addressing issues related to sexuality, as well as their adherence to social stereotypes and stigmas, and the repercussions for treatment, prevention and health promotion possibilities..$^{25,27-30}$

Challenges faced by health professionals in their daily practices

This category presents the perceptions of health professionals in relation to the personal and professional difficulties involved in their daily work of dealing with seroconverted elderly individuals in the public health sector.

With the exception of two health professionals (one mid-level and one higher level), all of the interviewees cited an excessive workload as their main problem on a daily basis, due to the insufficient number of doctors available to deal with the demand. They also referred to the psychic burden involved in their work. Three professionals (medicine and psychology) stressed the issue of psychic burden when treating elderly individuals with HIV/AIDS, as they listen to heart-wrenching storied on a daily basis about suffering, stigmas, prejudice and discrimination. They also stated that another element of the psychic burden of the work was the difficulties they experienced when trying to address the issues of sexuality and sexual activity with elderly patients, as can be seen in the following comment:

\footnotetext{
"HIV patients need us to provide a great amount of energy. So if we are not very well-balanced psychologically, or we don't have a great personal acquaintance, energy is like invisible radiation that destroys us on the inside, do you understand? The patients' stories are very upsetting, very sad. Often, we are one of the few people to whom they can say certain things. Therefore, the mental health of the staff who deal with AIDS patients must be given special attention". Med. 1
} 
The work of health professionals who care for HIV/AIDS patients should be structured by considering the need to offer support, solidarity, health education and information about how to prevent discrimination. In addition, feelings such as impotence, frustration, incompetence and frailty are common and the health professional must overcome their own taboos and prejudices in order to help patients face the crisis that began at the moment of diagnosis. ${ }^{16,17}$ These aspects help the overall understanding of the extent of the psychic burden mentioned in the interviews.

Together with this excessive workload, several other professional problems were mentioned by seven of the interviewees: 1) the need to create a transfer system for referral to specialized divisions within the public health service; 2) the multiple roles involved in certain professional categories; 3) the difficulty of actively searching for patients who do not adhere to their treatment; 4) the need to shed their prejudices on a daily basis and provide the best possible care for their patients; 5) the lack of weekly team meetings to discuss cases and work procedures; 6 ) the need for reflection with patients about quality of life rather than quantity of life.

Clearly, the difficulties reported by these health professionals demonstrate the precarious nature of the care provided, whether it be due to the insufficient number of doctors to meet the demand, the need for better patient flow and transfers, or the lack of support strategies for health professionals and service teams who deal with this complex issue. ${ }^{16,17,29,30}$ Furthermore, it is important to note that AIDS cases involve many demands that extrapolate the biomedical model of health care, requiring new training and professional activity parameters, focused on technical demands, psychosocial aspects and the need to coordinate multi-disciplinary teams for this type of work. ${ }^{16,17}$

The present study was developed with a restricted group of professionals. Thus, the results generated should not be generalized to other services. The aims of this research were the elucidation of the specificities of a specialized health care service. The relevance of this research is linked to its potential to contribute to the development of other studies that analyze this issue in greater detail, as well as to contribute to the analysis of convergence and divergence points of other scenarios that have been assessed. Considering the fact that qualitative and quantitative studies are complementary, the analysis generated could serve as a basis for the development of new and more extensive research projects.

\section{CONCLUSION}

Since social stereotypes and prejudice are elements of culture, and thus contribute to the formation of individuals and social relationships, it is essential that these discussions should be included throughout the health training process, both in terms of graduation and the permanent health training of health professionals, who need to be aware of the importance of these elements in health-disease processes and in health promotion strategies. The image of old age and the aging process, as well as the issues of sexuality and sexual activity among the elderly, remains a challenge for the health service and the promotion of healthy aging.

According to the perceptions of the health professionals, a diagnosis of HIV leads to the disorganization of how the subject views themselves, their lives and their personal relationships with other people. Consequently, they feel the need to reformulate these aspects of their lives.

In addition, the professionals noticed how a diagnosis of HIV for an elderly individual has great potential for stigmatization and causes great suffering. This pain is related to how they see themselves and how they feel they will be seen and judged by others. These experiences are also linked to the possibilities of treatment and health promotion.

In order to promote healthy aging, investment is required in health training and working conditions must be improved in public health care service units. 
Finally, due to the specific characteristics of qualitative surveys, the analysis used did not seek to establish generalizations related to the complexity of the situation analyzed, nor did it intend to exhaust the debate about the issues addressed. The results of the present study could contribute to the reformulation of health care

\section{REFERENCES}

1. Brasil. Ministério da saúde. Boletim epidemiológico: aids e DST ano II, no 01. Brasília: 2013. [Acesso em 2014 mai 13] Disponível em URL: http:// www.aids.gov.br/sites/default/files/anexos/ publicacao/2013/55559/_p_boletim_2013_internet_ pdf_p__51315.pdf

2. Smit M, Brinkman K, Geerlings S, Smit C, Thyagarajan K, Sighem A., et al. Future challenges for clinical care of an ageing population infected with HIV: a modelling study. Lancet Infect Dis [Internet]. 2015. [Acesso em 2015 nov 22]; 15: 810-818. Disponível em URL: http://www.thelancet.com/ journals/laninf/article/PIIS1473-3099(15)00056-0/ abstract

3. Brasil. Ministério da saúde. Boletim epidemiológico: aids e DST ano III, no 01. Brasília: 2014. [Acesso em 2015 nov 22]. Disponível em URL: http://www.aids. gov.br/publicacao/2014/boletim-epidemiologico-2014

4. Closs VE, Schwanke CHA. A Evolução do Índice de Envelhecimento no Brasil, nas suas Regiões e Unidades Federativas no Período de 1970 a 2010: Revista Brasileira de Geriatria e Gerontologia [Internet]. 2012. [Acesso em 2012 out 28]; 15 (3): 443-458. Disponível em URL: http://www.scielo.br/scielo.php?pid=S180998232012000300006\&script $=$ sci_arttext

5. Garcia GS, Lima LF, Silva JB, Andrade LDF, Abrão FMS. Vulnerabilidade dos idosos frente ao HIV/aids: tendências da produção científica atual no Brasil. DST - J Bras Doenças Sex Transm. [Internet]. 2012 [Acesso em 2014 out 15], 24(3):183-188; Disponível em URL: http://www.dst.uff.br/revista24-3-2012/7Vulnerabilidade_idosos_aids.pdf processes and subsidize public policies related to health promotion strategies for the elderly, while also bringing more attention to the problems faced. Further studies should be developed in an attempt to gain a better understanding of the stereotypes, stigmas and prejudice involved in health practices.
6. Batista AFO; Marques APO, Leal MCC, Marino JG, Melo HMA. Idosos: associação entre o conhecimento da aids, atividade sexual e condições sociodemográficas. Revista Bras. de Geriatria e Gerontologia [Internet]. 2011. [Acesso em 2013 nov 11]; 14(1):39-48. Disponível em URL: http:// www.scielo.br/scielo.php?script=sci_arttext\&pid =S1809-98232011000100005

7. Risman, A. Sexualidade e terceira idade: uma visão histórico-cultural: Textos Envelhecimento [Internet]. 2005. [Acesso em 2010 set 27]; 8(1): 89-115. Disponível em URL: http://revista.unati.uerj.br/ scielo.php?script $=$ sci_arttext\&pid=\$15175928200500 0100006\&lng $=$ pt\&nrm $=$ iso

8. Almeida, T, Lourenço, ML. Reflexões: conceitos, estereótipos e mitos acerca da velhice: Revista Brasileira de Ciências do Envelhecimento Humano [Internet]. 2009 [Acesso em 2010 set 26]; 6(2): Disponível em URL: http://revista.unati.uerj. br/scielo.php?script=sci_arttext\&pid=S180998232007000100008\&lng=pt\&nrm=iso

9. Silva VXL, Marques APO, Lyra-da-Fonseca JLC. Considerações sobre a sexualidade dos idosos nos textos gerontológicos: Revista Brasileira de Geriatria e Gerontologia [Internet]. 2009. [Acesso em 2012 out 28]; 12(2): 295-303. Disponível em URL: http://www. crde-unati.uerj.br/img_tse/v12n2/pdf/art_12.pdf

10. Brasil. Ministério da Saúde. Secretaria de Atenção à Saúde. Departamento de Ações Programáticas e Estratégicas. Atenção à saúde da pessoa idosa e envelhecimento. Brasília: 2010. [Acesso em 2014 mai 13] Disponível em URL: http://bvsms.saude.gov. br/bvs/publicacoes/atencao_saude_pessoa_idosa_ envelhecimento_v12.pdf 
11. Halter JB, Ouslander JG, Tinetti M, Studenski S, High K, Asthana S, et al. Hazzard's geriatric medicine and gerontology. 6.ed. New York: McGraw Hill Medical, 2009.

12. Silva LC, Felício EEEA, Cassétte JB, Soares LA, Morais RA, Prado TS, et al. Envelhecimento e HIV/ aids: contribuições da psicologia social ao ensino e pesquisa em saúde. CONVIBRA SAUDE [Internet]. 2013. [Acesso em 2013 out 23]; 1 (1) 1-12. Disponível em URL: http://www.convibra.com.br/upload/ paper/2013/59/2013_59_5813.pdf.

13. Goffman E. Estigma - Notas sobre a manipulação da identidade deteriorada. 4 ed. Rio de Janeiro: LTC Editora; 1988.

14. Guimarães, R, Ferraz, AF. A interface aids, estigma e identidade — algumas considerações: Revista Mineira de Enfermagem [Internet]. 2002. [Acesso em 2012 out 28]; 6(2):77-85. Disponível em URL: http://www.enf.ufmg.br/site_novo/modules/ mastop_publish/?tac $=$ Vol._6_n $\%$ BA_1\%2F2_ jan_.\%2Fdez._2002

15. Casaes, NRR. Suporte social e vivência de estigma: um estudo entre pessoas com HIV/AIDS. [dissertação de mestrado] [internet]. Salvador: Universidade Federal da Bahia, Faculdade de Filosofia e Ciências Humanas; 2007 [Acesso em 2012 fev 28]; Disponível em: http://www.pospsi.ufba.br

16. Fonseca, JFAMF da; Figueiredo, MA de C. Vivência profissional: subsídios à atuação em HIV/Aids: Revista Paidéia [Internet]. 2009. [Acesso em 2012 jun 13]; 19(42): 67-76. Disponível em URL: http://www. scielo.br/scielo.php?script=sci_arttext\&pid=S0103863X2009000100009

17. Shimma E, Nogueira-Martins MCF, NogueiraMartins LA. The experience of infectologists faced with death and dying among their patients over the course of the AIDS epidemic in the city of São Paulo: qualitative study. São Paulo Medical Journal [Internet]. 2010. [Acesso em 2011 mar 03]; 128(2): 7480. Disponível em URL: http://www.scielo.br/pdf/ spmj/v128n2/a06v1282.pdf

18. Ceccim, RB; Carvalho, Y. Formação e Educação em Saúde: aprendizados com a Saúde Coletiva. In: Akerman, M, organizador. Tratado de Saúde Coletiva. 2 ed. São Paulo: Hucitec; 2012. p. 149-182.
19. Monteiro S, Villela WV. Organizadoras. Estigma e saúde. Rio de Janeiro: Editora Fiocruz/FAPERJ; 2013.

20. Minayo, MCS. O desafio do conhecimento: pesquisa qualitativa em saúde.12.ed. São Paulo: Hucitec; 2010.

21. Banco de Dados do Serviço de Assistência Especializada, SAE [Internet]. Divinópolis-MG: Prefeitura Municipal de Divinópolis: 2012. [Acesso em 2013 out 04]. Disponível em URL: http://www. divinopolis.mg.gov.br/portal/noticia.php?id=10238

22. Bardin L. Análise de conteúdo. Lisboa: Edições 70; 2010.

23. Parker R, Aggleton P. Estigma, discriminação e AIDS. Coleção ABIA: Cidadania e direitos 2001; 1: 9-17.

24. Camargo BV, Barbará A, Bertoldo RB. Concepção pragmática e científica dos adolescentes sobre a AIDS: Psicologia em Estudo [Internet]. 2007. [Acesso em 2010 nov 27]; 12(2):277-84. Disponível em URL: http://www.scielo.br/pdf/pe/v12n2/v12n2a08

25. Freitas, MRI, Gir E, Rodrigues ARF. Compreendendo a sexualidade de indivíduos portadores de HIV-1: Revista da Escola de Enfermagem USP [Internet]. 2000. [Acesso em 2010 nov 27]; 3(3): 258-263. Disponível em URL: http:// www.scielo.br/pdf/reeusp/v34n3/v34n3a06

26. Guimarães, DA; Silva, ES. Formação em ciências da saúde: diálogos entre saúde coletiva e a educação para a cidadania. Revista Ciência \& Saúde Coletiva [Internet]. 2008. [Acesso em 2010 nov 04]. Disponível em URL: http://www.scielo.br/scielo.php?script=sci_ arttext\&pid=S1413-81232010000500029\&lng=pt\&nr $\mathrm{m}=$ iso\&tlng=pt

27. Melo HMA, Leal MCC, Marques APO, Marino JG. O conhecimento sobre aids de homens idosos e adultos jovens: um estudo sobre a percepção desta doença: Ciência \& Saúde Coletiva [Internet]. 2012. [Acesso em 201105 mar] 17(1): 43-53. Disponível em URL: http://www.scielo.br/pdf/csc/v17n1/a07v17n1.pdf

28. Driemeier M, Andrade SMO, Pontes ERJC, Paniago AMM, Cunha RV. Vulnerability to AIDS among the elderly in an urban center in central Brazil. Clinics [Internet]. 2012. [Acesso em 201105 mar] 67(1). Disponível em URL: http://www.scielo.br/scielo.php ?pid=S180759322012000100004\&script=sci_arttext 
29. Garcia GS, Lima LF, Silva JB, Andrade LDF, Abrão FMS. Vulnerabilidade dos idosos frente ao HIV/aids: tendências da produção científica atual no Brasil: DST - Jornal Brasileiro de Doenças Sexualmente Transmissíveis [Internet]. 2012. [Acesso em 2014 mai 11]; 24(3):183-188. Disponível em URL: http:// www.dst.uff.br/revista24-3-2012/7-Vulnerabilidade_ idosos_aids.pdf
30. Santos AFM, Assis M. Vulnerabilidade das idosas ao HIV/AIDS: despertar das políticas públicas e profissionais de saúde no contexto da atenção integral: revisão de literatura: Revista Brasileira de Geriatria e Gerontologia [Internet]. 2011. [Acesso em 2014 jan 21]; vol.14, n.1, pp. 147-157. Disponível em URL: http://revista.unati.uerj.br/pdf/rbgg/v14n1/ v14n1a15.pdf

Received: July 10, 2015

Revised: November 22, 2015

Accepted: July 08, 2016 